\title{
MANAGING AFRICA'S NATURAL RESOURCE ENDOWMENTS: NEW DISPENSATIONS AND GOOD-FIT APPROACHES
}

\author{
Kobena T. Hanson*
}

\begin{abstract}
Managing a nation's extractive natural resource endowments can advance national development if done meaningfully. Unfortunately, across Africa, the apparent mismanagement of such resources, poor growth rates, social tensions, and civil strife in resource-rich countries have thrown up a great deal of literature on what is now known as resource curse.It has also ignited calls for enhanced governance and improved capacities for the myriad of actors engaged in natural resource extraction. This article draws on the extant literature to interrogate the complex entanglements of issues involved in the natural resource value chain in Africa. It argues that in spite of the general ills, economic challenges, and socio-political pains that resource-rich African nations face in exploiting and managing their natural resources, the extractive industry in Africa is evolving positively, and that the situation of resource-rich African states is not immutable. Available evidence suggests that Africa is emerging a new, more complex, participatory, and coordinated vision of NRM; a development that offers opportunities and possibilities for Africa to engage emerging actors especially in the global South. The article concludes that what Africa needs is an approach with a good fit to local realities, and an enhancement of individual and institutional capacities.
\end{abstract}

Keywords: Africa, Capacity Development, Governance, Natural Resource Management.

DOI: https://dx.doi.org/10.4314/jsdlp.v8i1.6

\section{INTRODUCTION}

Africa's vast natural resources can spur development if managed properly. However, as experience shows, resource exploitation does not

* Chief Executive Officer, Strategic Outlooks, Ghana/KM Consultant, AfDB, P. O. Box CT9049, Cantonments, Accra, Ghana, E-mail: kthanson64@yahoo.com 
automatically translate into meaningful development. Across the continent, the exploitation and role of renewable (land, forests, water) and non-renewable natural resources - oil, gas and minerals such as copper, gold, coal, etc. - has, unfortunately, been central to the geopolitical, social and armed struggles. ${ }^{1}$ Sierra Leone, Liberia, and the Democratic Republic of Congo (DRC) immediately come to mind. Land grabs in Tanzania, Madagascar, DRC, and Ethiopia, to name a few, are also well documented. Again, the pollution of indigenous peoples lands in the Niger Delta region of Nigeria, the political unrest in Madagascar due to popular protest over the unfavourable land deals with South Korea, are well documented.

The terms resource curse, paradox of plenty and Dutch disease, are particular manifestations of the aforementioned negative relationship and, refer to forms of erosion of the broader economy. ${ }^{2}$ For example, the relationship between the rise in the exploitation of natural resources and a decline in the manufacturing sector (at times to include emergent industrial agriculture) reveals that comparatively greater revenues from natural resources can deindustrialize a national economy by raising the exchange rate, thus making the manufacturing sector less competitive. ${ }^{3}$

According to Karl, ${ }^{4}$ the resource curse or the paradox of plenty is explained by the fact that many of the oil-producing countries or petrostates are more dependent than other states on a single non-renewable commodity, and the exploitation of that commodity is more capital intensive, more enclave oriented, more centralized in the state, and more rent producing than any other, all of which bode ill for successful development. Revenue flowing through incapable or corrupt structures would have negative and perverse consequences on a country because

1 UNDP. Managing Natural Resources for Human Development in Low-Income Countries (Washington D.C.: UNDP - Regional Bureau for Africa, 2011).

2 Barma, N.H., K. Kaiser, T.M. Le and L. Viñuela. Rents to Riches: The Political Economy of Natural Resource-Led Development (Washington D.C.: World Bank, 2012), see alsoHumphreys, M., Sachs, J.D. and Stiglitz, J.E. Escaping the Resource Curse (New York: Columbia University Press, 2007).

3 Corden, W. and Neary, J. P. "Booming Sector and Deindustrialization in a Small Open Economy” (1982), Economic Journal, 92, 368: 825-848, see also Javaid, S.H. "Dutch Disease Investigated: Empirical Evidence from Selected South East Asian Economies" (2011), Journal of Economic Cooperation and Development, 32, 4: 61-74.

4 Karl, T. L. "The Perils of the Petro-State: Reflections on the Paradox of Plenty" (1999) Journal of International Affairs, 53, 1:31-48. 
the money was put to bad use, encouraged dependence on natural resources, and tended to result in corruption and a mono-industry economy. In particular, oil exports inflated the value of a country's currency and made its other exports uncompetitive.

In sum, natural resource extraction created and solidified asymmetries in wealth and increased the income gaps between the rich and poor; this, in turn, contributed to the institutionalization of corruption and enabled oppressive regimes to maintain their political power. ${ }^{5}$ This is a particular problem for resource-rich African economies which do not have a mature manufacturing sector able to withstand such a process, thus making them quite vulnerable to shocks. Indeed, poor growth rates, high inequality, social exclusion, impoverishment, poor governance, environmental concerns, social tensions, and civil strife characterize many resource-rich countries across Africa. ${ }^{6}$

Despite the evidence in the literature, and obvious challenges to the effective management of natural resources, some of the claims of the resource curse theorists have been challenged recently ${ }^{7}$ because the resource-conflict link is probably more complex than is conceptualized in the scientific mainstream. Others notice a considerable room for human agency to correct the risks posed by the paradox of plenty. ${ }^{8}$ Specifically for Africa, it has been argued that the resource curse paradigm hides the larger question of how institutions and their transformation affect growth. ${ }^{9}$ The importance of institutions derives from their offeringa structure required for the effective interaction of political and economic relations, or what North ${ }^{10}$ calls "the rules of the game".

5 Karl, T. L. The Paradox of Plenty: Oil Booms and Petro States (Berkeley: University of California Press, 1997).

6 Barma et al (n.2), see also Humphreys et al (n.2); Collier, P. The Bottom Billion: Why the Poorest Countries Are Failing and What Can Be Done about It. (New York: Oxford University Press, 2007).

7 Obi, C. "Oil Extraction, Dispossession, Resistance, and Conflict in Nigeria's OilRich Niger Delta" (2010), Canadian Journal of Development Studies, 30 (1-2): 219-236.

8 Humphreys et al (n.2); Barma et al (n.2).

9 Hanson, K.T., D’Alessandro, C., and Owusu, F. (eds.). Managing Africa's Natural Resources: Capacities for Development (Houndmills, Basingstoke: Palgrave Macmillan, 2014), see also ACBF (African Capacity Building Foundation). Africa Capacity Building Indicators 2013: Capacity Development for Natural Resource Management (Harare: ACBF, 2013).

10 North, D.C. Institutions, Institutional Change, and Economic Performance (New York: Cambridge University Press, 1990). 
In Africa, as indeed in many nations across the global South, discussions of the institutional structure inevitably lead to the state and its institutional apparatus in the development framework. ${ }^{11}$ Observably, the role of the contemporary African state in the development process has undergone dramatic changes due to or in response to globalization. The contestation suggests that policy outcomes are not predetermined, but rather contingent on the complexities in the relationship between state and non-state actors and institutions. It is for this reason that Basedau ${ }^{12}$ argues that contextual variables encompassing the national level must be taken into account in explaining why natural resources are sometimes detrimental to the development of a nation.

Such criticisms against the resource curse theorists shifted the initial debates to issues related to capacity, leadership, and governance, as the key drivers to negotiating the previously well-documented challenges of the natural resource sector. ${ }^{13}$ Thus, negotiating the curse is "inherently a governance challenge: the credibility, quality, transparency, and accountability of policy-making processes, public institutions, the legal and regulatory climate, and sector governance are major determinants of how successfully countries can channel their resource wealth into sustainable development."14

The resource curse thesis can, and should, be criticized on the grounds of its "evaluation methodologies and on the basis of measurement errors, incorrect specification of the models and the high probability of spurious correlations." 15 It will, at the same time, be hypocritical to ignore the general ills, economic challenges, and sociopolitical pains that resource-rich African nations face in exploiting and

11 Puplampu, K.P. "The Capacity Question, Leadership and Strategic Choices: Environmental Sustainability and Natural Resources Management in Africa" (2014). In Hanson et al. (eds.) (n. 9); see also Haslam, P. A., Schafer, J. and P. Beaudet. (eds.) Introduction to International Development: Approaches, Actors and Issues (2nd Edition. Don Mills: Oxford University Press, 2012).

12 Basedau, M. "Context Matters - Rethinking the Resource Curse in Sub-Saharan Africa" (DUI Working Papers \#1), (Hamburg: German Overseas Institute, 2005).

13 Hanson et al (n.9), see also ACBF (n.10).

14 Barma et al (n.2), 4.

15 UNRISD. "Report of the UNRISD International Workshop" (March 1-2, 2007), UNRISD Conference News. 
managing their natural resources. In fact, as Besada ${ }^{16}$ puts it, the historical and contemporary records of many resource-dependent African nations justify the concerns that have been evoked in the resource curse discussions.

The aforementioned notwithstanding, Africa's perceived resource curse is not inexorable. ${ }^{17}$ Some countries have been able to effectively manage their natural resources to spur development (e.g., Botswana), while others have recently revised/renegotiated contracts to ensure better outcomes (e.g., Liberia, Mozambique, Sierra Leone). Early in her administrationin Liberia, President Johnson Sirleaf ended decades of poorly managed extraction of timber resources by issuing Executive Order No. 1, declaring all forest concessions null and void and assigning the Forestry Development Authority (FDA), together with the Liberia Forest Initiative, with supervision of the reform process of the forest sector. ${ }^{18}$ In Mozambique, after an audit of investments between 2002 and 2008, the National Directorate of Lands and Forests cancelled or reduced the land area of 1500 investor contracts due to non-compliance with their investment plan. ${ }^{19}$ As these cases demonstrate, there is still agency at the national level for change, monitoring and holding accountable investors that fail to comply with their contracts. Observably the national level can often lack the knowledge, laws, institutions, and, importantly, the political will, to ensure that resource extraction projects are carried out responsibly, in ways that protect people and the environment. There are no "silver bullets that enable countries to avoid the resource curse and make the best possible use of natural resources for development," ${ }^{20}$ nonetheless, there are generally

16 Besada, H. "Doing Business in Fragile States: The Private Sector, Natural Resources and Conflict in Africa" (Background Research Paper Submitted to the High Level Panel on the Post-2015 Development Agenda (May 2013).

17 UNDP (n. 1).

18 Altman, S., Nichols, S. and Woods, J. "Leveraging High-Value Natural Resources to Restore the Rule of Law: The Role of the Liberia Forest Initiative in Liberia's Transition to Stability." In P. Lujala and S. A. Rustad (eds.), High-Value Natural Resources and Peacebuilding (London: Earthscan, 2012: 337-365).

19 Hanlon, J. "MOZAMBIQUE News Reports and Clippings", 190 (5 December 2011), see also Hanlon, J. "MOZAMBIQUE News Reports and Clippings", 187 (23 November 2011).

20 UNDP (n. 1), 2-3. 
steps that nations can take to mitigate the curse. ${ }^{21}$ The extant literature is focusing increasingly on capacityin addition to leadership and good governance as the way to negotiate and transcend the perceived curse. ${ }^{22}$

In arguing that the resource curse is not, and should not be seen as immutable, this article also submits that the often one-size-fits-all solutions that "best practice" approaches engender, need to be reconsidered. ${ }^{23}$ Rather, good-fit approaches that acknowledge the political economy context of a country should be embraced. Adopting the good-fit approach, will entail "an assessment of each country's political economy and institutional environment, including the type of natural resource available and its spatial distribution; the different stages of the natural resource value chain; the political, economic and institutional capability of country; and the different stakeholders involved." 24

\section{CAPACITY DEVELOPMENT IMPERATIVES ${ }^{25}$}

Within the African context, capacity is crucial because it is estimated that of the continent's vast resource wealth, only roughly 20 percent has been exploited. ${ }^{26}$ This reality, coupled with Africa's demographic dividend (notably its youth bulge), deepening political and macroeconomic reforms, and growing interest in its extractives driven by demand from the BRICS - notably China and India - have added

21 Hanson et al (n.9), see also Owusu, F., D’Alessandro, C. and Hanson, K.T. "Moving Africa Beyond the Resource Curse: Defining the "Good Fit: Approach Imperative in Natural Resource Management and Identifying the Capacity Needs." In Hanson et al (n.9), 206-25.

22 Hanson et al (n.9), see also Barma et al (n.2), Obi (n. 7), UNRISD (n.15).

23 Owusu et al (n.21), see also Barma et al (n.2).

24 Owusu et al (n.21), 207.

25 Capacity is theorized as "the ability of people, organizations, and society as a whole to manage their affairs successfully; and is the process by which people, organizations, and society unleash, strengthen, create, adapt, and maintain capacity over time. Capacity is also better conceptualized when answering the question: capacity for what? [and] is most tangibly and effectively developed in the context of specific development objectives such as [service delivery] ...; empowering local communities to better participate in public decision making processes; and promoting peace and resolving conflict" (ACBF 2011:30-31).

26 Collier, P. The Plundered Planet: Why We Must - and How We Can - Manage Nature for Global Prosperity (New York: Oxford University Press, 2010). 
implications. ${ }^{27}$ The presence of these major global players in the extractive sector not only brought large investments in the form of various infrastructural projects in recent years to the continent, but also led to strong price increases of extractives (at least up until the recent macroeconomic slow-down in China) reinforcing Africa's commodity dependence - or at the very least a distraction - for African policy-makers to accelerate their efforts towards diversification. ${ }^{28}$

Noteworthy is the growing interest and investments in the hydrocarbon and mineral sector from the Gulf, and to a lesser extent, the demand from the MINT nations.Over the past decade, there has been a marked increase in petrodollar investments from Gulf Cooperation Council (GCC) countries into Africa in the energy sector. Simultaneously, GCC countries have stepped up their importation of minerals from Africa (EIU 2011; UNCTAD 2014). The trend is generally expected to continueas the GCC forges ahead with its diversification strategy away from oil and into petrochemicals and other downstream manufacturing, but on a reduced scale due to the current global downturn in oil prices. ${ }^{29}$

Capacity issues such as undercapitalization, lack of competition, underperformance, investor-friendly and overgenerous legal framework, inadequate understanding of the technical aspects of natural resource management (NRM), and the domination of multinational corporations vis-à-vis a weak state are key obstacles to the transformation of Africa's natural resources into a blessing. The effectiveness of all policies to manage the risks associated with natural resources requires a strong

27 Hanson et al (n.9), see also Hanson, K.T., D’Alessandro, C., and Owusu, F. "Toward a Coordinated Approach to Natural Resource Management in Africa." In Hanson et al (n.9), 1-14; Le Billon, P. and Levin, E. "Building Peace with Conflict Diamonds? Merging Security and Development in Sierra Leone's Diamond Sector" (2009). Development and Change, 40, 4, 693-715; Maconachie, R. "Diamonds, governance and 'local' development in post-conflict Sierra Leone: Lessons for artisanal and small-scale mining in sub-Saharan Africa?" (2009) Resources Policy, 34, 1-2, 71-79.

28 Davies, M. "What China's economic shift means for Africa" (World Economic Forum Report, 2015). <http://www.weforum.org/agenda/2015/03/whatthe-shift-in-chinas-economy-means-for-africa > accessed January 22, 2016.

29 Torchia, A. and French, D. "Oil's Plunge to Siphon Gulf Petrodollars from Global Markets." Reuters Article (19 Jan. 2015). <http://www. reuters.com/article/ mideast-petrodollars-investment-idUSL6N0UE0ZI20150119> accessed January 21, 2016. 
institutional framework and the literature is clear that institutional weaknesses (corruption, lack of rule of law, weak governance) are major determinantsof the resource curse. ${ }^{30}$ According to the IMF," countries endowed with oil, gas and minerals face great policy challenges [partly because] national administrations are often weak, laws and regulations defective, and policies inadequate. Moreover, the overall governance environment is often poor. As a result, countries often do not receive fair compensation for their resources, and their spending does not produce the desired results." 31 Across Africa, the exploitation and governance of extractive resources (oil, gas and minerals such as copper, gold, coal, etc.) have, unfortunately, been central to the geo-political, social, and armed struggles. The Democratic Republic of Congo, Liberia, Sierra Leone, the Niger Delta in Nigeria and South Sudan immediately come to mind.Poor governance and weak regulatory frameworks also are central to the scourge of illicit financial flows. ${ }^{32}$

A number of capacity challenges have been identified across resource-rich Africa. The capacity of the legislature to act as a countervailing force over the executive and understand the complexity of natural resource legislation has been flagged. ${ }^{33}$ Aside from passing the annual budget, the legislature is responsible for ratification of natural

30 Ross, M. "Does Oil Hinder Democracy?” 2001. World Politics, 53, April, 325361, see also, Rosser, A. The Political Economy of the Resource Curse: A Literature Survey (2006), (Brighton: IDS (Working Paper No. 268); Rosser, A. "Escaping the Resource Curse" (2006). New Political Economy, 11, 4: 557-570.

31 IMF (International Monetary Fund). "IMF Launches Trust Fund to Help Countries Manage Their Natural Resource Wealth" (Press Release No. 10/497, 16 December 2010) <http://www.imf.org/external/np/sec/pr/2010/ pr10497.htm > accessed September 26, 2015.

32 AU/UNECA. Illicit Financial Flow: Report of the High Level Panel on Illicit Financial Flows from Africa (2014). <http://www.uneca.org/sites/default/files/ PublicationFiles/iff_main_report_26feb_en.pdf $>$ accessed 21 January 2016.

33 Ayee, J.R.A., Soreide, T., Shukla, G.P. and Minh Le, T. Political Economy of the Mining Sector in Ghana (World Bank Policy Research Working Paper, July WPS5730, 2011:1-48), see also Gboyega, A., Soreide, T., Minh Le, T. and Shukla, G.P. "The Political Economy of the Petroleum Sector in Nigeria" (2011) World Bank Policy Research Working Paper, August, WPS5779: 1-48; and UNECA. African Governance Report II (United Nations Economic Commission for Africa, Oxford: Oxford University Press, 2009). 
resource leases, contracts, and stabilization agreements. ${ }^{34}$ Observably, the performance of these responsibilities is generally subject to executive influence; thus, the checks and balances intended to secure independent control by the legislature in some African countries are rendered dysfunctional. Natural resources leases and other agreements with the companies first are brought to parliament (the legislature) to be ratified and then awarded to those companies. In most African countries, a select committee of the legislature on natural resources is responsible for conducting due diligence and examining the capacity, reputation, and finances of the company under review.

In a functioning system, if the company is deemed trustworthy and the proposal is in order, the contract or the agreement is cleared. Due precaution is supposed to be taken to avoid conflict of interest within the legislative select committee. If any matter under consideration before the committee could cause conflict of interest, these members have to recluse themselves. This may happen in practice as well, but this is uncertain because the supervision by the legislatures and their committees in Africa is not effective. ${ }^{35}$

Again, weak bureaucratic capacity prevents regulatory institutions from performing their functions effectively. ${ }^{36}$ That said, the lack of capacity is a function of the lack of political incentives to meaningfully invest in sector reforms rather than a quantitative indicator of a government's scarce human and material resources. Tackling poor regulatory capacity in this arena has not been a consistent priority. As Brautigam ${ }^{37}$ points out, central to the challenge is the "nature of African political regimes" often characterized by politics of patronage. As long as the leadership continues to engage in "arbitrary policy decisions not based on a careful analysis and rule mainly through patrimonial ties rather than rational legal norms, there will be little demand at the

34 Ayee, J.R.A. "The status of natural resource management in Africa: Capacity development challenges and opportunities," In Hanson et al. (eds.) Managing Africa's Natural Resources: Capacities for Development (Houndmills, Basingstoke: Palgrave Macmillan, 2014).

35 Ayee, J.R.A. (n.34), see also Ayee et al (n.33) and Gboyega et al (n.33).

36 AfDB (African Development Bank). African Development Report 2005: Public Sector Management in Africa (Oxford: Oxford University Press, 2005).

37 Brautigam, D. "State Capacity and Effective Governance" in (eds.), B.J. Ndulu and N. van de Walle, Agenda for Africa's Economic Renewal (New Brunswick/ Oxford: Transaction Publishers, 1996: 81-108). 
top for analytical capacity, technical skills, and good management in public administration." ${ }^{38}$ As a result, the natural resources industry is not being regulated effectively, essential analyses are not being undertaken, and most policy proposals are accepted without sufficient understanding of their implications. Following from this, capacity is lacking in the implementation of policies, programmes, and projects. ${ }^{39}$

Transfer pricing ${ }^{40}$ is yet another pressing challenge that has negatively affected revenue collections in some African countries. Most MNCs in the natural resources sector operate internationally and have extended dealings with affiliated companies, which increases opportunities for transfer pricing and potentially lowers the tax liability. This complicates the task of tax administration and creates a challenge that requires serious attending to. ${ }^{41}$ Africa, it is estimated, lost approximately US $\$ 850$ billion in illicit financial flows (IFFs) between 1970 and 2008, and over US\$1 trillion in IFFs over the last 50 years a figure roughly comparable to the development assistance that the continent received during the same period.

The AU/UNECA ${ }^{42}$ define illicit financial flows as "money that is illegally earned, transferred or utilized," and that typically originates from one of three sources: (1) commercial tax evasion, trade misinvoicing and abusive transfer pricing;(2) criminal activities, including the drug trade, human trafficking, illegal arms dealing, and smuggling of contraband; and (3) bribery and theft by corrupt government officials. ${ }^{43}$ Many African tax laws have legal provisions meant to address the challenge, however these provisions are insufficient. The tax administration personnel need better training on how to recognize the transfer pricing opportunities in natural resources operations and stronger capacity to detect and respond to this problem. Failure to

38 Ibid. 89.

39 UNDP (n.1).

40 Transfer pricing refers to the setting of the price for goods and services sold between controlled (or related) legal entities within an enterprise. For more, see for example KPMG (2014) <https://www.kpmg.com/Global/en/ IssuesAndInsights/ArticlesPublications/global-transfer-pricing-review/ Documents/gtpr-2014-full-report.pdf>

41 Africa Progress Panel. Africa Progress Report 2013. Equity in Extractives. Stewarding Africa's Natural Resources for All (Geneva: Africa Progress Panel, 2013).

42 AU/UNECA (n.32).

43 Ibid. 
grasp its sophisticated and complex nature will seriously erode the tax base in most African countries. ${ }^{44}$ Yet another area that urgently needs attention is the generous concession that governments grant to MNCs in the natural resources sector and which cannot be altered even when the conditions in which they were signed have change substantially or unexpectedly ex post. ${ }^{45}$ Consequently, attempts at contract renegotiation have not only been contentious but have reflected institutions' weak capacity to engage MNCs meaningfully, particularly in the face of the resources at their disposal. ${ }^{46}$ Countries that have recently renegotiated extractive contractssuccessfully, some with the expert assistance of the African Legal Support Facility of the AfDB), include DRC, Guinea, Liberia, Niger, Tanzania, and Zambia. ${ }^{47}$

Then again, governments' capacity to address the domestic side of natural resource governance - for example, effective distribution or use of the revenue generated from natural resources to prevent conflict - has been an issue. Good resource management involves accountability on how these resources and wealth are used. Good resource management ensures that everyone benefits from the resource wealth in a fair and equitable manner. Unfortunately, across Africa, resources have been a blessing for a few and a curse for many - the latter often being the population and the localities from where resources are extracted. ${ }^{48}$ This problem can be attributed to poor resource manage-

44 Brautigam, D., Fjeldstad, O-H. and Moore, M. (eds.) Taxation and State-Building in Developing Countries: Capacity and Consent (Cambridge: Cambridge University Press, 2008).

45 ACBF (n.9).

46 WTO. World Trade Report 2010: Trade in Natural Resources (Geneva: World Trade Organization, 2010), see also Gaille, S. "Mitigating the Resource Curse: A Proposal for Microfinance and Educational Lending Royalty Law" (2011), Energy Law Journal, 32: 81-96.

47 ALSF. 2014 African Legal Support Facility Annual Report (Abidjan: African Legal Support Facility, 2015), see also Botchway, F. N. and Rukuba-Ngaiza, N. "The Constitutional Regime for Resource Governance in Africa: The Difficult March toward Accountability", in (eds.) J. Wouters, A. Ninio, T. Doherty, and H. Cisse. Improving Delivery in Development: The Role of Voice, Social Contract and Accountability (World Bank Legal Review Vol. 6, 2015). Washington, DC: World Bank: 149-170.

48 Obi (n.7). 
ment, a problem in many resource-rich countries in Africa. ${ }^{49}$ A good example is the Niger-Delta region, Nigeria's largest oil producing region but the poorest because it has not benefited from the oil wealth derived from oil production. ${ }^{50}$ Similar cases can be found with oil in Angola and diamonds in the Democratic Republic of Congo and Sierra Leone, two countries that have experienced both extreme poverty and violent civil wars. ${ }^{51}$

Capacity issues equally plague Africa's artisanal and small-scale mining (ASM) sectors. ${ }^{52}$ ASM activities in Africa are estimated to engage about 8 million workers, who in turn support about 45 million dependents. ${ }^{53}$ Furthermore, the number of ASM miners is growing as a result of rising commodity prices and limited economic opportunities in other sectors. In Ghana, for example, ASM contributed nine per cent of total gold production in 2000, rising to 23 per cent by 2010 . ASM is also a vital livelihood source for women across rural resourcerich African countries providing impoverished women and families with economic opportunities that might not otherwise exist. ${ }^{54}$

Sadly, this aspect of the mining industry across Africa is poorly carried out due to the weak/non-existent technical capacities required to identify, plan, develop, and exploit high value resources. As a result, small-scale stakeholder extractive activities fail to take full advantage of the overall value of the resource while, at the same time, consuming or contaminating other resources - such as wood and other forest resources, land, and water, which are essential to livelihoods and food security, particularly once the extractable resource is exhausted. Thus, as currently conducted in many countries, artisanal and small-scale

49 Onigbinde, D. Natural Resource Management and its Implications on National and Sub-regional Security: The Case of the Niger Delta (2008). Kofi Annan International Peacekeeping Training Centre (KAIPTC) (Occasional Paper No. 22: 1-23).

50 Ikelegbe, A. "The Economy of Conflict in the Oil Rich Niger Delta Region of Nigeria" (2006). African and Asian Studies, 5, 1:23-55; see also Obi (n.7).

51 Onigbinde (n.49).

52 Hayes, K. and Perks, R. "Women in the Artisanal and Small-Scale Mining Sector of the Democratic Republic of the Congo." In: P. Lujala and S. A. Rustad (eds.) High-Value Natural Resources and Peacebuilding (London: Earthscan, 2012).

53 Benkenstein, A. "Artisan and Small-scale Mining in Africa: Opportunities and Challenges" (SAIIA Blog, 1 March 2012). Johannesburg: South African Institute for International Affairs. Accessed January 24, 2016.

54 Hayes, K. and Perks, R. (n.52). 
mining delivers short-term monetary gains to miners and traders who are involved directly, but it also worsens local poverty for many others. In the DRC, artisanal and small-scale mining has been linked to armed conflict where minerals extracted by artisanal workers were used to purchase weapons and fund other aspects of the conflict. ${ }^{55}$

To further highlight the urgency of capacity for natural resources management, consider that even though oil, gas and metals are of strategic importance, they do not even account for 5 percent of total global production of goods and services, making the importance of Africa's raw materials relative. ${ }^{56}$ While there may be substantial natural resources reserves in Africa, in most cases, the heart of usage - especially in the extractive industries, lies outside Africa. Despite Africa being top in the production of diamonds, gold, cobalt and platinum, it is obvious that most of these minerals are exported in their raw form to developed economies and to emerging economies. ${ }^{57}$ Even where resource-rich African states try to generate revenue via exports, this effort is still insignificant. ${ }^{58}$ Foreign markets, be it the traditional Western nations or increasingly emerging economies such as the MINTs/ BRICS/GCC, still unduly determine the path of Africa's economic growth and development irrespective of the natural resource endowments, due to the structural dependency of African economies on natural resources in its raw/unprocessed form.

The aforementioned suggests several policy actions. For one, the existing human, institutional and infrastructural capacity deficiency must be sufficiently addressed. ${ }^{59}$ There is the need also for technical capacity to independently explore known and unknown natural resource deposits, independently appraise finds and properly evaluate their worth, assess investor work plans so as to maximize the real rate of recovery and return from natural resources, and several other technical functions.Africa's think-tanks could lead this effort. African nations

55 Ibid.

56 ACBF (n.9).

57 See also Ramdoo and Bilal. 2014. On Beneficiation/Upstream and Downstream Linkages/The "Smile Curve", etc.

58 Geda, A. "Resource Flows From Booming Natural Resource/Primary Commodity Sectors in Africa and Their Macroeconomic Policy and Capacity Building Challenges" (2012). (ACIR 2013 Background Paper No. 2), Harare: ACBF.

59 Besada, H., Lisk, F. and Martin, P. "Regulating Extraction in Africa: Towards a Framework for Accountability in the Global South" (2015), Governance in Africa, 2(1): 1-12; see also Barma et al (n.2). 
dependent on resource exploitation also need to particularly be capable of securing political and social stability. This calls for leadership capacity to develop strong policy instruments including, but not limited to, clear and well-conceived regulations and mining codes to manage the inflows of foreign direct investments (FDI). Such capabilities also include how a country manages at different levels - local, country, or regional level - to aggregate and address citizen needs, include diverse societies in decision-making (women and excluded groups), and enhance accountability of public officials to the citizenry. If countries are unable to secure social and political stability, and they are rich in natural resources, they remain poor and mired in conflict. ${ }^{60}$ The conflicts in Sierra Leone and Liberia in the 1990s, the crises in Nigeria's Niger Delta region, and the ongoing strife in the eastern parts of the DRC are reflective of this. ${ }^{61}$

Yet another key capability is that of tapping benefits from trade and integration which presupposes the capacity to put in place an enabling environment with property rights, rule-based governance, a sound business regulatory environment, a functioning financial sector and effective trade policies. ${ }^{62}$ Countries also need to have skills to negotiate, discuss and secure the appropriate terms of trade, trade policies, and engage in fair contractual agreements. ${ }^{63}$ Efforts by postcivil war Liberia, and Mozambique in the timber industry, Sierra Leone in the minerals sector, and the AfDB's African Legal Support Facility

60 Ismail, O. and Okeke, J.M. "Criminality in the Natural Resource Management Value/Supply Chain.” In Hanson et al (eds.) Managing Africa's Natural Resources: Capacities for Development (Houndmills, Basingstoke: Palgrave Macmillan, 2014).

61 NATO. "Global dynamics of national security: alliances and resources - The future of resource conflicts: The Africa pattern. NATO" (2012). <http:// www.libraryindex.com/pages/1941/Global-Dynamics-National-SecurityAlliances-Resources-FUTURE-RESOURCE-CONFLICTS-AFRICAPATTERN.html> accessed February 10 2015; see alsoRustad, S. A. and Binningsb $\emptyset$, H. M. Rapid recurrence: Natural resources, armed conflict and peace. Oslo: Peace Research Institute Oslo (Working Paper, Center for the Study of Civil War, 2010).

62 Rustad, S., Lujala, P. and Le Billon, P. "Building or Spoiling Peace? Lessons from the Management of High-Value Natural Resources." In P. Lujala, and S. A. Rustad (eds.), High-value natural resources and peacebuilding (London: Earthscan, 2012: 570-621).

63 Ibid. 
(ALSF) ${ }^{64}$ assisting countries' negotiation of extractives contracts are all steps in the right direction. ${ }^{65}$ That said, there is a high need for management capacity to remove constraints that bottleneck the effective extraction of resources, notably supply chain bottlenecks (transport logistics, business climate).

Again, having the requisite capacities to track the impact of different economic policies, particularly those that help countries manage the boom and bust cycles inherent in dependency on natural resources, is also required. ${ }^{66}$ Such capabilities include having a cadre of individuals and institutions that can formulate, implement, and evaluate macroeconomic, fiscal, and debt policies. Citizens also expect that a country rich in natural resources should be able to deliver services effectively, which presumes a quality public administration, efficient resource mobilization, and superior budget and financial management capabilities. Price fluctuations and changes in terms of trade also necessitate critical capabilities of managing within uncertainties, and being ready for the emerging challenges such as climate change. Such uncertainties require countries to have skilled people, well versed in sustainability thinking for development programmes and policies and institutions for environmental sustainability. ${ }^{67}$

Last but not least, effective management capacity to negotiate the dynamic interactions between large-scale mining companies and the local/indigenous artisanal and small-scale mining sector are critical for building domestic legitimacy for resource extraction and for reducing potential sources of conflicts over resource extraction. ${ }^{68}$ Managing the relationship must be premised on a tacit recognition that small/ artisanal mining has a legitimate and significant role to play in the

64 The ALSF is an independent international African institution established in 2008 to provide legal advice and technical assistance to African countries in matters pertaining to creditor litigation and complex commercial transactions. ALSF assists countries in acquiring effective legal assistance in dealing with vulture fund negotiations and litigation, and accessorily acquiring the requisite legal capacity on a reimbursable fee-basis to negotiate complex commercial transaction. For more, kindly see: alsf@afdb.org.

65 Hanson et al (n. 90), see also Barma et al (n.2).

66 ACBF (n. 9) see also Geda (n. 58).

67 Hanson, K. and Léautier, F. A. "Enhancing Institutional Leadership in African Universities: Lessons from ACBF's Interventions" (2011). World Journal of Entrepreneurship, Management and Sustainable Development, 7(2/3/4): 386417.

68 Owusu et al (n.21). 
socio-economic development of African countries. It must also acknowledge their potential competition for the same mineralization, impacts on livelihoods if access to resources is limited, and changing social conditions, including conflict between artisanal/small mining, locals, and large-scale mining companies. Some large-scale mining operations have recently published a set of approaches and tools for mining companies to engage with artisanal/small mining. ${ }^{69} \mathrm{~A}$ key aspect of the guidance is that all International Council on Mining and Metals (ICMM) members will implement the Sustainable Development Framework, report their performance against the 10 principles in accordance with GRI guidelines, and offer third-party verification that companies are meeting their commitments to the 10 principles. While this is a good start, governments must take this to the next level by addressing some of the demands of artisanal mining in their specific national contexts.

\section{NEW DISPENSATION IN NATURAL RESOURCE MANAGEMENT IN AFRICA}

Studies suggest that a wave of new optimism is sweeping across Africa - rising GDP, consumer spending increases, and returns on investments are higher than global averages. ${ }^{70}$ Recent publications all highlight an evolving natural resource landscape in Africa. ${ }^{71} \mathrm{RWI},{ }^{72}$ for instance, notes that Ghana, Guinea, Liberia, South Sudan, and Zambia have all recently reformed their oil or mining legislation to include some principles of open government (e.g., all public data are made available [Open], and available to anyone [non-discriminatory]). Similarly, the growing exposure of the problem of "missing revenues" and growth of corporate social responsibility programmes, extensive and participatory discussions of value chains and jobs, development of trust funds/

69 See ICMM. 2010. "Working Together:How large-scale mining can engage with artisanal and small-scale miners." < http://www.icmm.com/page/17638/newpublication-on-engaging-with-artisanal-and-small-scale-miners $>$ accessed on 8 February 2015.

70 McKinsey Global Institute. Lions on the Move: The Progress and Potential of African Economies (2010). McKinsey Global Institute <www.mckinsey.com/ mgi>.

71 Hanson et al (n. 9), see also ACBF (n.9), Africa Progress Panel (n.41), Revenue Watch Institute. The 2013 Resource Governance Index (RWI, 2013).

72 RWI (n.71). 
sovereign wealth funds (Angola, Nigeria, Ghana, Tanzania), and the increasing mobilization of community interests (Ghana, Nigeria), and community-based NRM are all images of this evolving landscape. ${ }^{73}$ Another manifestation of the changing landscape is the African Mining Vision (AMV), which was adopted by African Heads of States and Governments in February 2009. ${ }^{74}$

Even as initiatives such as the EITI, Publish What You Pay (PWYP), and the Kimberley Process Certification Scheme (KPCS) continue to monitor resource extraction activities, UNEPS International Resource Panel (IRP) is steadily building up an understanding of global resource flows and why economic growth needs to be decoupled from rates of resource extraction. However, for the aforementioned initiatives, and others such as the Natural Resource Charter (NRC) (www.natural resourcecharter.org) and AMV to really benefit Africans as a whole, there is the "need for greater ownership and buy-in by African citizens ... and greater policy space for [countries] to regulate and monitor resource extraction for the benefit of their populations." 75

The apparent damaging situation of resource-rich economies in Africa is not immutable. ${ }^{76}$ Many agree that better governance, transparency and accountability are central to good resource management, ${ }^{77}$ and can help enhance the potential value of natural resource endowments. ${ }^{78}$ Studies suggest that the legacy of oldnatural resource management landscape, characterized by asymmetries of weak states versus strong external actors (MNCs, consumer countries); low and often erratic commodity prices; unfair terms of trade; low technological and managerial capacity; insufficient and ineffective legal frameworks and policies; weak bargaining capacity and systems of taxation; lack of transparency and accountability across the value-chain; windfall rents,

73 ACBF (n. 9).

74 ECA/AU (Economic Commission on Africa/African Union Commission). Economic Report on Africa 2013: Making the Most of Africa's Commodities: Industrializing for Growth, Jobs and Economic Transformation (Addis Ababa, Ethiopia: ECA/AU, 2013).

75 Africa-Canada Forum. The African Mining Vision: A Transformative Agenda for Development (2013). <http://www.ccic.ca/files/en/working_groups/201304-02-AMV_backgrounder_EN.pdf $>$ accessed October 4, 2015.

76 ACBF (n. 9), see also Obi (n. 7).

77 NRC (The Natural Resource Charter). Natural Resource Charter (November, 2010). <www.naturalresourcecharter.org > accessed October 3, 2015.

78 Collier (n.26). 
when realized, extracted for benefit of only the elite; lack of economic diversification and shared growth; unmitigated environmental damage caused by extraction process; and the socio-cultural displacement of affected communities is giving way to an evolving positive landscape. ${ }^{79}$

Today, internal and external pressures have resulted in a growing state coherence with strong policy frameworks and increased regional and sub-regional integration and linkages. Recent developments at enhanced cooperation in the East African Community, or among stakeholders along the Maputo Corridor, are good examples. This, coupled with high, if still erratic, commodity prices on Africa's extractives, driven by a strong demand from BRICs; advancements in technical skills (law, science, management); a recognition of need for training programmes; extensive discussion of value chains and jobs; development of trust funds/SWFs; the promotion of green growth, REDD + (Reducing Emissions from Deforestation and Forest Degradation), national and international NGOs environmental advocacy; a proliferation of CSOs with increased capacity and international linkages; and new configurations of dialogue (among public, private, NGOs, and communities), have contributed to the increased rejection of blood diamonds, conflict timber, abuses of MNC oil and gas extraction; even as national governments advance initiatives such as the African Peer Review Mechanism (APRM), Africa Mining Vision (AMV), African Minerals Development Centre (AMDC), ${ }^{80}$ and AfDB's African Legal Support Facility. ${ }^{81}$

The entire portfolio of stakeholders is subject to a new normative environment, as evidenced by the strong natural resource management policy environment emerging across Africa. ${ }^{82}$ Policies frame the sphere of potential constructive action; there are now new spaces for agency. The increases in the global prices of extractives over the past decade,

79 Barma et al (n.2).

80 The AMDC was launched in December 2013 to strategically coordinate the implementation of the African Mining Vision (AMV). Amongst others the AMDC coordinates the provision of technical support for the implementation of the AMV, identifies gaps and areas of need and potential expertise to address those needs, undertakes/coordinates policy research, undertakes advocacy and information dissemination, monitoring and evaluating activities relating to the implementation of the AMV, and provides a think tank capacity for the AMV and the activities around it. Visit http://www.uneca.org/amdc for more on AMDC.

81 Hanson et al (n.9).

82 RWI (n.71). 
coupled with the expansion of new discoveries, and a growing demand from emerging economies, for a while represented an unparalleled opportunity for Africa's resource-rich states to bolster transformation within the ongoing evolving landscape. However, the recent global downturn in oil prices, and the slow-down in China, has drastically affected markets and investments in the industry. ${ }^{83}$ Enhancing the investment climate is one of the central steps to advancing international competitiveness in Africa's resource-rich economies. ${ }^{84}$ Countries need to advance and entrench policies that acknowledge the realities of their national contexts, that can bring about rapid results in a context of urgent need, and that allow for incremental improvements to their governance processes. ${ }^{85}$

The ongoing developments are in the right direction, however, resource-rich African states need to embrace policies and initiatives that aim to sustain the current momentum. As Page ${ }^{86}$ points out, much of Africa's post-1995 growth acceleration has been primarily driven by "avoiding the policy mistakes that led sharp economic contractions in the past and by a strong surge in growth in the resource-rich economies." To sustain and enhance the gains already achieved, resource-rich African states must also seek creative ways (such as institutionalized peer-topeer learning programmes, and knowledge management systems) to overcome the knowledge asymmetries that they face in negotiations with foreign stakeholders; even as they develop appropriate tax structures, and invest in advancing capacity in all sectors along the entire natural resources value-chain. ${ }^{87}$

In Ghana, for example, Tullow Oil Plc in collaboration with the British Council in Accra, launched the Tullow Group Scholarship Scheme to provide annual scholarships to 50 Ghanaians to pursue postgraduate

83 England, A. "African Growth Feels the Strain from China's Slowdown." Financial Times (27 October 2015). <http://www.ft.com/cms/s/0/ef4d851a-7bc5-11e598fb-5a6d4728f74e.html\#axzz3yBPBF4iz> accessed 24 January 2016.

84 Page, J. "Rowing Against the Current: The Diversification Challenge in Africa's Resource-Rich Economies" (2008). Global Economy \& Development Working Paper 29. Washington, DC: Brookings.

85 Marcel, V. Guidelines for Good Governance in Emerging Oil and Gas Producers (September 2013). London: Chatham House (The Royal Institute of International Affairs).

86 Page (n.84).

87 Marcel (n.85), see also RWI (n. 71), ECA/AU (n. 74). 
programmes abroad. In Botswana the opening of the Debswana complex, representing a fifty-fifty joint venture between De Beers and Botswana, including a US $\$ 35$ million state-of-the-art diamond sorting, valuing, and selling centre, called DTC Botswana, has contributed to the skills development of locals in the diamond industry - sorting, and valuing gems which previously was done outside the country. Ensuring that Africa's natural resource endowments translate into meaningful development, will also require building meaningful partnerships based on trust, mutual interests, and common understanding of challenges, opportunities and possibilities. ${ }^{88}$

As Marcel ${ }^{89}$ also notes, "instead of encouraging [African countries] to pursue "best practice" standards, it may be more helpful to advise them to aim for more appropriate practice, which acknowledges the realities of the national context,more effective practice which seeks to bring about rapid results in the context or urgent needs, or better practice, which aims at incremental improvements of governance processes through aspirational, but achievable, milestones." Marcel, thus, concurs with Barma et al, ${ }^{90}$ and Owusu et al, ${ }^{91}$ who all call for a good-fit approach to natural resource management in Africa.

\section{GOOD-FIT APPROACH TO RESOURCE MANAGEMENT}

The recognition of the centrality of national political and economic context in resource management has led to calls to de-emphasize the so-called best practices and promote good-fit policies in resource-rich African countries. ${ }^{92}$ Proponents of the good-fit policies argue that welfare-promoting policies, institutions, and governance must be tailored, at least in part, to suit each country's specific context. ${ }^{93}$

88 Lisk, F., Besada, H. and Martin, P. "Regulating Extraction in the Global South: Towards a Framework for Accountability" (2013). Background Research Paper, Submitted to the High Level Panel on the Post-2015 Development Agenda (May).

89 Marcel (n.85).

90 Barma et al (n.2).

91 Owusu et al (n.21).

92 Ibid.

93 Diamond L. and Mosbacher, J. "Petroleum to the People: Africa's Coming Resource Curse - and How to Avoid It", Foreign Affairs (September/October 2013). <http://www.foreignaffairs.com/articles/139647/larry-diamond-and-jackmosbacher/petroleum-to-the-people> accessed 7 September 2015. 
According to Barma, ${ }^{94}$ policies will be effective in leveraging natural resource-led development only when such policies are compatible with the level of institutional quality and the political economy context of the country in question. Accordingly, designing natural resource management policies for any country should be preceded by an assessment of that country's political economy and institutional environment as it relates to natural resource management and, on that basis, develop a "set of targeted prescriptions across the natural resource value chain that are technically sound and compatible with the identified underlying incentives." 95 Much like the other proponents of the institutional explanation, Barma et $a l^{96}$ not only make a case for good-fit policies for resource-rich African countries, but also go a step further and argue that identifying what are the good-fit policies requires a good understanding of the national context. ${ }^{97}$

Given that countries face different hurdles as they proceed along the natural resource value chain, ${ }^{98}$ including their ability to include the dynamic feedback loops in their decision making process,good-fit approaches must acknowledge the enormous variations among the resource-endowed African countries in terms of the political and economic conditions, institutional quality, and capacities. ${ }^{99}$ For instance, the natural resource management challenge will vary for fragile/failed states such as South Sudan, for post-conflict states such as Sierra Leone, as well as for stable states such as Botswana. ${ }^{100}$ Accordingly, the capacity needs and sequencing of such needs will vary and must be recognized as such. Doing so, helps reinforce the call for good-fit policies, with tailor-made solutions/strategies, based on the assessment of the country's political economy. Depending on country-specific contexts, it may be appropriate in one stead to pursue institutional capacity development first, as opposed to individuals. In other situations, it

94 Barma et al (n.2).

95 Ibid., 3.

96 Ibid.

97 Owusu et al (n.21).

98 The NRM value chain spans the key sequence of steps that a resource-dependent country must undertake in transforming its natural resource into developmental aspiration. These include sector organization and contract awards, regulation and monitoring operations, collection of taxes and royalties, revenue distribution and management, sound and sustainable policies (ACBF 2013).

99 Besada (n.16).

$100 \mathrm{ACBF}$ (n.9). 
will be better to invest first in the capacity of the legislature, as opposed to say the capacity of the government or civil society. ${ }^{101}$

Implementing the good-fit approach thus entails tailoring interventions to the national context and developing an incentive structure that supports and nudges stakeholders into making developmentally oriented decisions. The importance of governance, leadership, and stakeholder' engagement in this effort cannot be overemphasized. ${ }^{102}$ However, an understanding of the roles and capacities of the various stakeholders and a renegotiation of their mandates with an eye toward more interdependence, coordination, and mutual monitoring must herald the good-fit approach. ${ }^{103}$

An anticipated change that will result from the good-fit approach involves governance arrangements that stress the role of civil society. As local communities increasingly assert their voice in negotiations of resource exploration, especially in the extractive sector, civil societies have emerged as crucial governance actors, demanding a greater share of benefits for the long-term development of the local communities and increased their involvement in decision-making in natural resource management. ${ }^{104}$ The extractive industry developer's embrace of Social License to Operate (SLO), local content strategies and the desire to manage the relationship between local and large-scale miners are examples of how African governments can help chart out alternative natural resource governance that are more reflective of each nation's context, as well as avoiding potentially costly conflicts and exposure to social risks. ${ }^{105}$ SLO is becoming increasingly relevant for mining companies due to their ability to ensure that local stakeholders remain supportive of projects.

Another tactic being usedby some African countries to wade off

101 Ibid.

102 Puplampu (n. 11).

103 Owusu et al (n.21).

104 Greenspan, E. "Free, Prior, and Informed Consent in Africa: An Emerging Standard for Extractive Industry Projects" (2014). Oxfam America Research Backgrounder Series <www.oxfamamerica.org/publications/fpic-in-africa >, see also Owusu (n. 21), and Lujala, P. and Rustad, S. (eds.) High-Value Natural Resources and Peacebuilding (London: Earthscan, 2012).

105 Prno, J. and D. Scott Slocombe. "Exploring the Origins of 'Social License to Operate in the Mining Sector: Perspectives from governance and Sustainability theories" (2012). Resources Policy, Vol. 37: 346-367, see also Pike, R. "The Relevance of Social License to Operate for Mining Companies" (Schroders Social License to Operate Research Paper, July 2012). 
local discontent is the introduction of requirements for local content ${ }^{106}$ into their regulatory frameworks. ${ }^{107}$ Successful local content programmes such as CDC Development Solutions in Angola ${ }^{108}$ or the Minerals and Mining Act (2006)/the Minerals and Mining (General Regulation 2012) (LI 2173) of Ghana require good and clear understanding of the business benefits and a well-defined strategic plan adapted to the country's situation. Hence, a nuanced appreciation of the local context is vital for effective SLOs in terms of requirements, capabilities, and the barriers that limit local worker and local company participation. These factors will vary by location, nature and stage of project life cycle.

\section{CONCLUSION}

Africa is at a crossroads in terms of growth, development, governance, and sustainability. ${ }^{109}$ Available evidence suggests that Africa is evolving a new, more complex, evidence-based, participatory, and coordinated vision of natural resource management: a vision of natural resourcebased development motivated by an increasingly diversified and empowered portfolio of stakeholders and actors - indigenous groups/ communities, civil society, media, governments, multi-national corporations, and private investors.

A broad capacity development of all actors (i.e., investors, civil society, locals, and government) is desirable, and gradually pursued by countries across the region, although it is usually unrealistic in the time frame of resource exploitation priorities and processes, and in

106 Local content refers to strategies to ensure that outputs from the extractive industry sector generate further benefits to the local economy beyond the direct contribution of its value-added, through its links to other sectors (Tordo and Anouti, 2013). The requirements for local content strategy include creating jobs, promoting enterprise development, and accelerating the transfer of skills and technologies (IPIECA 2011).

107 IPIECA. Local Content Strategy: A Guidance Document for the Oil and Gas Industry (London, UK: IPIECA, 2011).

108 Levett, M. and Chandler, A.E. Maximizing Development of Local Content Across Industry Sectors in Emerging Markets (Washington, DC: Center for Strategic and International Studies, 2012).

109 Hanson, K., G. Kararach and T. Shaw (eds.) Rethinking Development Challenges for Public Policy: Insights from Contemporary Africa (London: Palgrave Macmillan, 2012). 
particular given the other needs that prevail in the African context. The essential things, therefore, are the focused approaches needed to attend to near-term capacity problems, while simultaneously pursuing deeper institutional capacity development. One practical approach in acute settings is to enhance the capacities of opposed sets of actors to act as checks on one another. The UN has done considerable work on the problem of capacity imbalance/sequencing, particularly in the context of peace negotiations. Its experiences can be applied widely for the benefit of all resource-rich, but often capacity-poor African countries to enable them advance good-fit approaches, and thereby negotiate/transcend the perceived resource curse. In addition, African countries need to draw on the experiences and lessons of nations (both in the global North and South) that have successfully managed natural resource endowments to spur development and prosperity. To this end, insights from Norway, Chile, Vietnam, and Botswana could provide valuable learning for African nations.

The winds of change sweeping the continent need to be sustained, and to do so will require the active engagement of all stakeholders in the natural resource value chain - communities, civil society, media, governments, multinational corporations, Africa's regional and continental bodies, as well as development partners. It also calls for leadership capacity, functional institutions and a sustained drive to seek out good-fit policies that advance institutions and governance system tailored, at least in part, to suit each country's specific context. 